DOI: https://doi.org/10.31392/NPU-nc.series9.2018.18.02

UDC: $81^{\prime} 0$

\author{
Nataliia M. Bober \\ Kyiv National Economic University \\ named after Vadym Hetman, \\ Kyiv, Ukraine
}

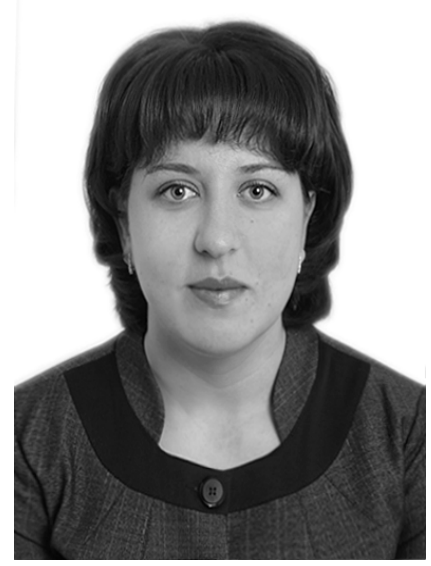

\title{
ENGLISH PHRASAL VERBS AS COGNITIVE AND SEMANTIC COMPLEXES AND FRAGMENT OF MULTILATERAL KNOWLEDGE OF MATRIX FORMAT
}

\section{Bibliographic Description:}

Bober, N. M. (2018). English Phrasal Verbs as Cognitive and Semantic Complexes and Fragment of Multilateral Knowledge of Matrix Format. Scientific Journal of National Pedagogical Dragomanov University. Series 9. Current Trends in Language Development, 18. 22-32. DOI: https://doi.org/10.31392/NPU-nc.series9.2018.18.02

\section{Abstract}

The article suggests a novel approach to the study of the English phrasal verbs, which is currently at the frontier of the cognitive syntagmatics. Based on the works in this domain, this paper specifies the definition of phrasal verbs as cognitive-semantic complexes which represent / describe a certain fragment of multidimensional knowledge of the matrix format. Particular attention is paid to the critical analysis of the scholars' views on the problem of the second component of these entities, which to this day are not univocal both in terms of discussing their functions performed in the structure of the phrasal verbs, and of their morphological nature and the associated terminology.

It is assumed that the semantics of the phrasal verbs is created by the interaction of the conceptual structures of both the verb, and its second component, where the abstract meaning of the latter gives wide opportunities for evolving of new meanings. In this case, the function of both components of a compositionally complex linguistic unit or a cognitive-semantic complex, which is a phrasal verb, consists in the profiling of certain aspects of the situation described by this formation, contributes to the new properties, which otherwise cannot be individually described/labelled by none of its components: neither the verb nor the post-positive component.

It has been proved that the English language possesses a characteristic cognitive-semantic construct "verb + postpositive component" that reflects a certain grammatical pattern of the combinatorial construction of phraseological entities bases on the mechanisms of conceptual integration, when the metaphorical selection of the verb initial mental space and the initial space of the postpositive component form a new blend - a new conceptual structure which absent in the initial mental spaces of each of the components.

Keywords: phrasal verbs, cognitive-semantic complex, postpositive component, matrix format, conceptual integration. 


\section{Introduction. New Preconditions for the Study of Phrasal Verbs.}

Current verbal semantics in general and phrasal semantics of verbal complexes in particular are primarily discussed in the context of three key concepts: 1) structural and semantic syntax once initiated by (Tesnière, 1988), 2) new theory of verbal syntagmatics (Ufimtseva, 2002: 135-137), and compositional semantics (Kubryakova, 2015), based on which, according to Ufimtseva, "[...] the verb, in conjunction with other parts and in its various word-building combinations [...] displays [...] minimal discrete fragments (quanta) of reality [...]" (Ufimtseva, 2002: 135-137), and, of course, 3) cognitive syntagmatics (Vlavaczkaya, 2013 et al.) closely related to Fauconnier and Turner's conceptual integration theory.

Representatives of all three concepts have prepared a powerful ground for developing a new theory of cognitive and semantic reconstruction of verbal syntagmatics mechanisms, which will allow approaching to the solution of extremely complex and still controversial issue of ontological and epistemological essence of phrasal nature of English verbal constructs (for details, see Petrovich) and proving an assumption that such constructs have matrix nature and are the products of conceptual integration of language phenomena in general. Petrovich expresses the same opinion in her thesis: "[...] reconstruction of the process of phrasal verb formation and identification of conceptual contribution of the components of such verb are quite possible and necessary procedures for identification of its nature" (Petrovich, 2004: 7).

However, in spite of strong tradition of studying English phrasal verbs as a specific construct of this particular language, as a result of which the scientists (both experienced and young) 1) defined semantic and derivative structure of such constructs (Anichkov, 1997; Grigoriyev, 2003; Zhluktenko, 1954; Ivashkin, 1988; Kubryakova, 1975; Belaya, 1995; Bogdanova, 2006; Voskres, 2017; Biber, 1999; Lindner, 1982; Meyer, 1975; Povey, 1990, and more); 2) presented characteristics, including terminological, of the second component (Viktorova-Orlova, 1978; Kuznetsova, 1998; Nogina, 1988; Paliy, 2008; Chibisova, 2009; Brinton, 1988, and more); 3) categorized them in texts, discourses, and corpuses (Vanivska, 2010; Golubkova, 1990, 2002; Petrova, 2012; Sizova, 2004; Shaposhnikova, 2003, Bolindger, 1971; Povey, 1990, and more), we believe that cognitive essence of an element that follows the verb requires deeper consideration in terms of previously researched matters (for details, see (Nikolenko, 1999), while the role of that element has only recently begun to be reconsidered in terms of its semantic capabilities as part of a verb phrase.

\section{Aim.}

The aim of the article is to consider English phrasal verbs of as cognitive and semantic complexes, formed as a result of mechanisms of conceptual integration.

\section{Cognitive-Grammatic Approach to the Study of Phrasal Verbs.}

This new turn in the study of English verbal and phrasal constructs is primarily caused by domination of cognitive and semantic concept in grammar, which contributed to a change in traditional view of the verb's nature as a lexicogrammatical class of words and pushed the researchers (see Lebedeva, and her school students' concept of polysituational analysis of the verb) to consider the verb, according to Kubryakova "as a designation of reduced situations rather than designation of various processes, actions, or states, which is correct but not sufficient" (Kubryakova, 2004). In this regard, it is important to understand which cognitive structures are actualized in the native speakers' minds in connection with certain verbal form (in our case, a phrasal verb (Lindner, 1982). Incidentally, according to Tom MacArthur, the term, phrasal verb, was first introduced in 1925 by Logan Smith in his scientific paper, Words and Idioms, where he said that a publisher had prompted him to use such term.

And if the formulation of the issue is exactly like this, we assume that identification of ontological essence of phrasal verb as a cognitive and semantic complex, where both components play important role in the formation of the verb's idiomatic meaning, is an equally important subject of discussion (it is exactly the idea that was the basis for Smith's paper and was even included in its name). 
In order to confirm the formulated hypothesis, we will analyze the scientists' ideas regarding their understanding and interpretation of phrasal verb, principles and criteria of its various taxonomies. Most importantly, and this requires special focus, the essence of the second component (its morphological and syntactically valent and distributive connectivity, that is the mechanisms of combinatorial syntagmatics) is still very narrow and even terminologically unclear.

Preliminary critical analysis of the above opinions of the authors of various scientific papers on this issue gives ground to state that the overwhelming majority of scientists (Dido,2016; Malykh, 2009; Chibisova, 2009 and more) refer to and rely on the interpretation of a phrasal verb given in Povey's Phrasal Verbs And How To Use Them, where the researcher listed the most important, in her opinion, characteristics of a phrasal verb (Povey, 1990: 8-11), which include: 1) mandatory phrasal verb transformation to a simple verb, 2) idiomaticity, 3) ability to form passive constructs (so called passivization), and 4) ability to create interrogative pronoun forms such as who $(m)$ or what rather than adverb forms such as where.

Jane Povey deduces such characteristics (which, from our standpoint, cannot be ontologically exhaustive for identification of its grammatical and semantic nature) from her own definition of a phrasal verb, which is reproduced in numerous recent articles and theses and which she understands as "a combination of a simple verb (come, put, go, etc.) and adverbial postword (in, off, up, etc.), which constitute / form a single semantic and syntactic unit" (Povey, 1990: 4). But such explanation still rightfully causes criticism from linguists (Chibisova, 2009: 179), which, in its turn, does not contain sufficiently convincing arguments, being limited to questions to the author such as: Is it possible to consider the combinations defined by Jane Povey as phrasal verbs based on suggested characteristics as none of them is completely reliableamong a large number of such constructs and their variants, there are numerous exceptions (Malykh, 2009: 106).

Indeed, combinations of verbs that are considered as phrasal is a separate issue. Particularly, such combinations (see (Yatskovich, 2000)) include both actual phrasal verbs (constructs similar to verb + particle / postverb / postpositive, etc. as a conditional term) and constructs such as verb + verb (make do), verb + preposition (dispose of), verb + particle + preposition (put up with), which only emphasizes terminological confusion. Despite lengthy discussion, the issue remains open to date.

In recent articles (Yatskovich, 2000), attempts are increasingly made to assign a phraseological status to phrasal verbs, i. e. to consider them in the context of phrasal constructs consisting of verbs and postverbs (specific construct that is neither an adverb nor a preposition), and the above examples of verb + other components combination are suggested to be differentiated based on their idiomaticity (actual phrasal verbs) / non-idiomaticity (not phrasal verbs). Such criterion is also suggested by Povey (see above).

One should agree that English phrasal verbs are idioms but cannot be reasonably classified as phraseological constructs - most of them are formed based on cognitive process of metaphorization rather than actual phraseologization (as demonstrated below). Therefore, we support the idea that it is still difficult to draw a clear line between actual phrasal verbs, phraseologisms, on the one hand, and verbs with "pure" adverbs and prepositions, on the other hand.

We will try to demonstrate our view and give answer to this question after a critical review of the papers that discuss the matters related to the issue, which were formulated above. Particularly, we will demonstrate the scientific aspect of our own considerations.

Convincing arguments for the formulation of optimal well-founded definition of a phrasal verb lie in such scientific fields as combinatorial syntagmatics and conceptual integration theories, in terms of which one should consider the mechanisms of combining the verb and its components as a cognitive and semantic complex, which is a fragment of English native speakers' matrix format knowledge regarding the situation / fragment of reality represented by such complex. 
To this end, the primary task is to analyze the scientists' views before trying to understand and terminologically interpret the second component added to the verb, such views currently being inconsistent and not unanimous. In this context, consider rightful Paliy's assumptions (see

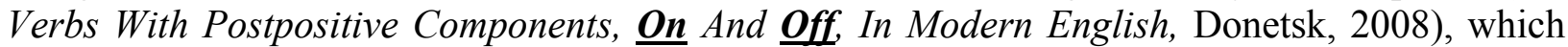
claim uncertainty of the nature of verbal postpositive component, its categorical status and complicated semantic structure.

\section{Categorial Status and Cognitive-Semantic Gist of Post-Positive Component.}

First of all, two issues are still disputable: 1) terminological designation of the second component and 2) its morphological essence. In the above paper, Paliy, following Amosova (Amosova, 1963), calls the element attached to the verb a postpositive component as compared with different adjacent and synonymous doublets such as adverbial postposition (Anichkov (1947)), prepositional adverb (Berlizon, 1954; Karyagina, 1977), adverbial particle (Zilberman, 1955; Povey,1990), particle (Linder, 1983); postverb (Dukhon, 1983), postpositive prefix (Zhluktenko, 1954), verb-adverb complex (Voskres, 2014), etc. and defines it as "a postverb component, which, due to the weakening of its adverbial function, forms more or less stable semantic and syntactic combinations with verbs" (Paliy, 2008). However, new papers, the ideas of which are based on Linder and her followers' papers, try to persuade us that such repeatedly replicated and somewhat obsolete understanding of postpositive component does not contribute to answering the above two issues. In her thesis, Paliy, unfortunately, analyzes its superficial nature reduced to word-building and semantic essence of the phrasal verb in general, etc. rather than its cognitive essence.

Indeed, phrasal verb definition in Petrovich's paper (Cognitive Basis For The Formation Of New Phrasal Verbs In Contemporary English, Kalinigrad (2004)) is sound and enables to comprehend the ontological nature of the postpositive component - phrasal verb is defined as a derivative unit (secondary nomination product), the semantics of which is based on interaction of conceptual structures of the verb and the particle. In such case, phrasal verb is a special compositional or integrative construct with a specific type of meaning (as defined by Kubryakova), which is not completely reduced to the meaning of its parts (Petrovich, 2004: 6-7) (it is not about weakening, particularly, of the functions of the second component - our clarification $-N$. B.), but is constructed according to Langacker's cognitive grammar laws.

Obviously, the simplified vision of grammatical and semantic essence of the phrasal verb complex caused a discussion problem, which scientists have tried to solve according traditional compatibility theory, which later developed as an individual field of combinatorial syntagmatics. Key elements of the theory are as follows.

In the times of classical structural linguistics, the issues of linguistic signs combinatorics, according to Vlavaczkaya, were researched in terms of syntagmatics / actual connectivity theory, which included the analysis of linear relations between linguistic signs. Back then (in the middle of the XX century), the linguists understood that the study of syntagmatic structure of a language should become an individual area of language studies, which will directly cover the rules of language units' combination depending on the given meaning (Vlavaczkaya, 2013: 3).

Without going into detailed history of development of the above theory, note that after lengthy discussions about valency as a key term of syntagmatics, mainly associated with Tesnière, who defined it as verbs' connectivity rules based on their ability and possibility to attach a certain number of actants (Tesnière, 1988), the term is now considered as the words' paradigmatic and semantic ability to form valence bonds with other components in a sentence not only with verbs. In his theory, Tesnière considered sentences as an implementation of syntactic valency of words but still emphasized the key role of predicate in a sentence. And in this regard, his standpoint regarding the valence partially coincides with Katsnelson's position, who also considered the incompleteness of a statement in the context of predicate verb (Korolyova, 2018). 
The most promising and optimal definition of valency was suggested by Boguslavsky, implicitly reflecting its connections and relations with the context of a statement. "Valency, as noted by Boguslavsky, is the ability of word L to describe a situation with participant X [...]. Accordingly, a word has as many valencies as the number of participants (semantic actants) of the situation that shall be described to fully interpret its meaning" (Boguslavsky, 1996).

The represented view on the essence of valency suggests that, in a broad sense, it is about a cognitive character of category thay reflects native speaker's ability to connect certain linguistic units in a particular communication situation, which is called the regular context, or the environment (Ispiryan, 2012: 75). To that end, the context is understood as a verbal environment of a linguistic unit, which is now associated with the concept of distribution rather than valency when considering various connections of a word with other words (see Kochergan, Word and Context) in a particular communication situation.

The issue of phrasal verbs and verb connections with the second component became an individual aspect of this trend in English. The issue of nature of connection between the components, reflecting either their analytically verbal or syntactic essence, caused lively discussion.

Scientists who defended the functional equivalence of phrasal verbs with individual analytical words (Anichkov, 1992; Zhluktenko, 1954; Nikolenko, 1999; Smith, 1998, etc.) believed that postpositive component is a word-building element that modifies or radically changes the meaning of the source verb. Meanwhile, the opposite vision was stated by researchers who considered the second component as an adverb or preposition (Arnold, 1985; Gursky, 1975; Smirnitsky, 1998, etc.), and the status of the entire verbal complex as a verbadverb or, respectively, verb-preposition construct with varying degree of compatibility and, naturally, valent or distributive connections.

Well-founded are the opinions of supporters of the first standpoint, which gave priority importance to the postpositive component as such (although they erroneously considered phrasal verbs as analytical words rather than combinations of two independent components), which radically changes the meaning of the verb associated with the postpositive component - we believe it has more abstract semantics and actualizes new meanings of a verb with more specific semantics (e.g., the verbs reflecting emotional states of a human). At the same time, the significance of the theory of adherents of the second approach lied in the fact that they attempted to solve the problem of connectivity / syntagmatics (valency / distributivity) of both components of a verb phrase. We believe that results of studies of supporters of both approaches have gradually raised the question of exact scheme of interaction between the components of complex units of different order such as phrasal verbs.

\section{Theory of Conceptual Integration and Its Role in Revealing the Mechanisms of Phrasal Verbs Formation.}

At the beginning of the XXI century, scientists initiated the study of this issue in the context of the theory of conceptual integration (Kubryakova, 2004; Fauconnier, Turner, 2002; Sweetser, 2000, etc.), which is considered to be one of the most common cognitive operations, where source connected mental spaces (actual verb as a structure describing the situation and postpositive component with its spatial semantics) create a new integrated structure that develops according to own laws (Petrova, 2004: 5), that is according to cognitive grammar.

Langacker's cognitive grammar theory states that description of any item or situation is determined by native speaker's choice of certain parameters (e.g., the level of specification, definition of certain component as a part of the whole, etc.) and the designation that best describes such choice. Therefore, linguistic signs are essential as constructs that give access to various conceptual structures of consciousness, activating their individual parts necessary for understanding of the meaning of name/expression and its adequate interpretation rather than names / designations of respective situations. In terms of cognitive grammar, this process involves profile superimposition over the base (Petrova, 2004: 14). In such case, the base is a 
conceptual matrix consisting of comprehensive set of respective cognitive structures and the profile is the base structure (Langacker, 1988), which is actualized with a phrasal verb. Therefore, the function of both components of a compositionally complex linguistic unit, or, according to our terminology, a cognitive and semantic complex (a phrasal verb), lies in profiling (Langacker, 1991), or cognitive emission (Kucher, 2015), of certain aspects of the situation described by this construct, which contributes to formation of new properties that none of the components (neither a verb nor a postpositive component) could describe / designate separately.

Such direction of phrasal verbs study was first suggested in the 80 s by Lindner, who considered phrasal verb as a construct encoding the entire integrated scene. Each component of such construct emits certain aspects of the scene (Lindner, 1983: 251). Phrasal verb as a combination of two equally important components superimposed on each other is the result of formation of a new meaning. Lindner rejects standpoints and taxonomies of phrasal verbs where the postpositive component, which Lindner calls a particle, seemingly does not have own meaning. She believes that phrasal verb particles always encode certain semantic component of such verbs. Moreover, individual phrasal verbs (semi-idiomatic) should be analyzed based on the meaning of particles rather than verbal elements, because the former have more general (abstract) meaning which is further specified through the semantic range of respective verbs.

The scholar suggests to consider the meaning of a particle within phrasal verbs as a set of certain interrelated meanings and their generalizations (schemes) that have something in common with specific verbal meanings but are more abstract. The meaning of a particle sets a series of configurations with a verb - from direct meaning to figurative, typically metaphorical.

Let us give examples from the paper of Petrovich's, who analysed Pamela Morgan's cognitive metaphorical approach (Morgan, 1997: 345) to identification of the essence of a particle within a phrasal verb and metaphorization of the entire cognitive and semantic phrasal verb complex.

The phrasal verb, figure out, is the result of four metaphorization processes. Firstly, the verb, to figure (which means "to manipulate numbers") derived from the noun using metonymy acquires more abstract meaning "to reach a solution by thinking", using conventional metaphor that conceptualizes thinking as a form of calculation. Secondly, the direct meaning of postpositive, out ("not within the boundaries of a container"), is extended and now correlates, in the minds of native speakers, with things that are pictured / conceptualized as a container. Thirdly, from these two sources of domains - directly from the verb, to figure, using conceptual metaphor THINKING IS CALCULATING, and the postpositive component, out, using conceptual metaphor A PROBLEM IS A LOCKED CONTAINER - a newly created phrasal verb, to figure out, gives the target domain the meaning: "to make a solution cognitively accessible by thinking". As a result, the phrasal verb, to figure out, becomes an integrated construct (in our terminology, a cognitive and semantic complex - N. B.) both cognitivosemantically and syntactically. And, finally, fourthly, conceptual metaphor KNOWING IS SEEING (based on metaphor INACCESSIBLE IS OUT / VISIBLE IS IN) is activated, forming the content of the phrase, to figure out a solution ("causing smth to be known by thinking about if' (Petrovich, 2004: 25).

It is what the matrix format of phrasal verb lies in; such format can be reconstructed with mechanisms of conceptual integration of mental spaces, which, as shown by the previous example, are organised using cognitive models. The model of conceptual integration of phrasal verb includes two source mental spaces - the space of the verb, to figure, and the space of the postpositive component, out, between which there is a cognitive operation involving connection of elements of both structures based on similarity and analogy (Fauconnier, Turner, 2003). In the cognitive metaphor theory, such cognitive operation is called mapping (Lakoff (1995) et al.) and in the theory of classical verb syntagmatics, such complicated mechanism of mapping, or conceptual integration, was attempted to be explained through ready-made morphological and 
semanticosyntactic configurations of adverbial or prepositional component and the verb, that is strictly linguistically rather than cognitively.

Common conceptual features of the verb and the postpositive component combining the source mental spaces are projected in so-called generative space based on a complex cognitive and combinatorial syntagmatic mechanism. During conceptual integration, a new model of generative space is transferred to each of the models of initial mental spaces, ensuring structural coherence of their elements. It is followed by selective integration of structures and elements of source models to create a new space, the blend, which results in the integrated structure (in our case, the phrasal verb) with a new meaning. A new meaning (new structure of consciousness) is created using three cognitive operations: 1) combination of elements of source mental spaces and establishing relations / connections between them; 2) formation of new background conceptual structures and their reflection in the native speakers' minds; 3 ) comprehension / interpretation of the new structure. G. Fauconnier and Turner note that the above operations are performed instantly, which means that their sequence is a rather conditional scientific explanation of conceptual integration phenomenon (Fauconnier, Turner, 2003).

Integrated mental spaces reflect one of the fundamental properties of human thinking and language - ability to combine language signs in a particular situation of their use based on cognitivogrammatical and lexicosemantic connections of the components of newly created language constructs as a result of structuring of the experience represented in their meanings.

This reasons our assumption that English phrasal verbs are cognitive and semantic complexes representing a certain fragment of matrix format multidimensional knowledge (structured experience).

As a result of interaction of conceptual structure of the verb and the postpositive component, a new conceptual structure is created, absent in source mental spaces of each of the components. During conceptual integration, the connections between the blend (a new meaning of verb phrase complex) and the generative space and between the blend and source mental spaces are maintained. A phrasal verb becomes the linguistic fixation of new conceptual structure and the resulting blend is a new construct of the situation.

Conceptual integration creates a cognitive and semantic complex of verb and postpositive component (consisting of two structures: 1) new meaning of phrasal verb and 2) combination of verb and postpositive component) due to generation of new knowledge apprehensible to English native speakers.

\section{Conclusions.}

To summarize, note that the process of English phrasal verbs formation can be reconstructed based on conceptual integration theory. It is reduced to the formation of a blend (new meaning of phrasal verb) during conceptual integration of source mental space of both the verb and the postpositive component. Elements of source spaces and relations that connect them are projected by metaphorical selection. Specific feature of phrasal verbs formation is that categorical meaning of the verb is always projected in the blend from the verb's source space, which becomes the basis of the blend structure. The blend, that is a phrasal verb, as a new combinatorial structure, is not copied entirely from source spaces but is generated by combining projections from source spaces, background knowledge of English native speakers and mental reflection of the fragment of reality designated by the construct in their minds. Therefore, there is a cognitive and semantic construct: verb + postpositive component in English, which reflects certain grammatical scheme of conceptually combinatorial design of phrasal constructs. This process, as well as entire mechanism of conceptual integration, is both innovative and conservative. Its innovativeness lies in selective metaphorical projection of conceptual structure from initial spaces and the action of involving the background knowledge, while the conservativeness is in formally grammatical expression of phrasal construct according to English grammar. 


\section{References} vo LGU.

Amosova, N. N. (1963). Osnovy angliyskoy frazeologii [Fundamentals of the English phraseology]. L. : Izd-

Anichkov, I. E. (1992). Idiomatika i semantica [Idiomatics and semantics]. Voprosy yazykoznaniya, 5.140150.

Anichkov, I. E. (1997). Trudy po yazykoznaniyu [Works on linguistics]. sostavitel i otvetstvennyi redactor prof. V. P. Nedyalkov. $\mathrm{SPb}$ : Nauka.

Arnold, I. V. (1986). Leksikologiya sovremennogo angloyskogo yazyka [Modern English Lexicology]. 3-e izd., pererab. i dop. M. : Vysshaya shkola.

Avdevich, N. V. (2007). Kognitivno-diskursivniye sobennosti mnogozhanchnyh frazovyh glagolov $v$ sovremennom angliyskom yazyke: na materiale frazovyh glagolov deystviya s chastitsami on / off [Cognitivediscursive features of polysemic phrasal verbs in the modern English language: on the material of phrasal verbs of action with particles on / off]: Thesis: 10.02.04. M. : MGLU.

Basyrov, Sh. R. (2004). Tipologiya glagolov s refleksivnym kompleksom $v$ indoyevropeyskih yazykah [Typology of verbs with reflexive complex in Indo-European languages]. Donetsk : DonNU.

Belaya, G. E. (1995). Strukturno-semanticheskiye i funktsionalniye kharakteristiki glagolnyh analiticheskih leksem $v$ sovremennom angliyskom yazyke [Structural-semantic and functional characteristics of verbal analytical lexemes in modern English: author's abstract]: Thesis' Abstract: 10.02.04. M. : Moskovskiy pedagogicheskiy gosudarstvennyi universitet im. V. I. Lenina.

Berlizon, S. B. (1957). Grammaticheskiye osobennosti glagolno-narechnyh frazeologicheskih yedinits v sovremennom angliyskom yazyke [Grammatical features of verbal-adverbial phraseological units in modern English]. Uchen. zapiski Magnitogorsk. Ped. In-ta, 11. 312-322.

Berlizon, S. B. (1964). Sochetaniya tipa make up, make for v sovremennom angliyskom yazyke [Make up, Make for combinations in modern English]. M. : Prosveshcheniye.

Biber, D., Johansson, S., Leech, G., Conrad, S., Finegan, E. (1999). Grammar of Spoken and Written English. London : Longman.

Bogdanova, S. U. (2009). Kognitivnye osnovaniya analitizma (na primere angliyskih frazovyh glagolov) [Cognitive bases of analyticism (on the example of the English phrasal verbs)] Kognitivnye kategorii $v$ sintaksise: collective monograph. otv. redactor Kovalyova L. M. Irkutsk : IGLU.

Boguslavskiy, I. M. (1996). Sfera deystviya leksicheskih edinits [The lexical units operation scope]. M. : Shkola "Yazyki russkoy kultury".

Bolinger, D. (1971). The Phrasal Verb in English. Cambridge, Massachusetts : Harvard University Press.

Brinton, L. J. (1988). The Development of English Aspectual Systems. Aspectualizers and postverbal particles. Cambridge : CUP.

Chibisova, E. U. (2009). Angliyskiye frazovye glagoly i ih upotrebleniye v yuridicheskih dokumentah [English phrasal verbs and their use in legal documents]. E. U. Chibisova. Almanah sovremennoy nauki $i$ obrazovaniya, 2 (21), 3. 178-181.

Courtney, R. (2000). Angliyskie frazovye glagoly. Anglo-russkiy slovar [English phrasal verbs. EnglishRussian dictionary]. 2-e izd., stereot. M. : Russkiy yazyk.

Dido, N. D. (2016). Do pytannya vyvchennya frazovyh diyesliv v angliskiy movi: El. resurs [To the problem of studying phrasal verbs in the English language: E-resource]. Retrieved from : https://www.google.com/url.

Dukhon, B. M. (1983). Modelirovaniye konstantno-variativnyh otnosheniy v semantike kompleksov tipa "to make up" [Modelling of constant-variational relations in the semantics of "to make up" complexes]: Thesis: 10.02.04. M. : MGLU.

Fauconnier, G. (1998). Mental Spaces: Aspects of meaning Consttuction in Natural Language. Cambridge : Cambridge Univ. Press.

Fauconnier, G., Turner, M. (2003). The way we think: conceptual blending and the mind's hidden complexities. Basic Books.

Golubkova, E. E. (1990). Glagolniye kompleksy tipa come in, put away v sovremennom angliyskom yazyke: semantika i funktsionirovaniye [Verb complexes, e.g. come in, put away in modern English: semantics and functioning]: Thesis: 10.02.04. M. : MGLU.

Golubkova, E. E. (2002). Chastitsy around, round, about kak modifikatory znacheniya angliyskogo glagola dvizheniya [Particles around, round, about as modifiers of the meaning in the English verb of motion]. Kompozitsyonnaya semantika: materialy tretiyey mezhdunarodnoy shk.-seminara po kognitivnoy lingvistike, 1. 124126. 
Golubkova, E. E. (2002). Frazoviye glagoly dvizheniya (kognitivnyi aspect) [Phrasal verbs of movement (cognitive aspect)]. M. : GEOS.

Goursky, S. E. (1975). The Idiomatic Heart of the English Language. Lvov: United Publishing House "Vyshcha Shkola".

Grigoriyev, S. V. (2003). Frazovye glagoly [Phrasal verbs]. SPb : KARO.

Ispiryan, A. V. (2012). Sochetayemost v nauchnom modelirovanii [Compatibility in scientific modeling]. Sovremennaya filologiya: teoriya I praktika: materialy of IX mezhdunarodnoy nauchno-prakticheskoy konferentsii, October 2-3. 74-75.

Ivashkin, M. P. (1988). Sinkhronno-diahronicheskiy analiz perehodnyh protsessov $v$ angliyskom yazyke [Synchronic-diachronic analysis of transient processes in the English language]. M. : Prometey.

Ivashkin, M. P. (1989). Perehodniye protsessy I zony $v$ sfere funktryonirovaniya glagolno-narechnyh sochetaniy tipa come up, rule in v angliyskom yazyke [Transients processes and zones in the functioning of the verbadverb combinations of come up, rule in type in the English language: diss. of Doct. of Philology]: Thesis: 10.02.04. Gorkiy : GGPIIYA im A. I. Dobroliubova.

Karyagina, N. F. (1977). Sintagmaticheskiy $i$ paradigmaticheskiy ellips $v$ glagolnyh konstruktsiyah $s$ predlogom i predlozhnym narechiyem $v$ sovremennom angliyskom yazyke [Syntagmatic and paradigmatic ellipse in verbal constructions with a preposition and a prepositional adverb in modern English]: Thesis' Abstract: 10.02.04. M. : MGPIIYA.

Kirilenko, E. I. (1992). Razlichitelniye koponenty frazovyh glagolov [Distinctive components of phrasal verbs]. Logisheskiy analiz yazyka. Modeli deystviya. 155-160.

Kochergan, M. P. (1980). Slovo i kontekst [The word and the context]. Lviv : Vyshcha shkola.

Korolyova, A. V. (2018). Reconstruction of Early Migration Routes of Homo Populations. Logos, 94. 159166. doi: 10.24101/logos.2018.16

Korolyova, A. V. (2018) Combinatorial Syntagmatics: from the Theory of Valency to the Theory of Conceptual Integration. Scientific Journal of National Pedagogical Dragomanov University. Series 9. Current Trends in Language Development, 17. 99-111.

Kubryakova, Ye. S. (1992). Glagoly deystviya cherez ih kognitivniye harakteristiki [Verbs of action through their cognitive characteristics]. Logicheskiy analiz yazyka: modeli deistviya. 85-86.

Kubryakova, Ye. S. (2002). Kognitivnaya lingvistika i problemy kompozitsionnoy semantiki v sfere slovoobrazovaniya [Cognitive linguistics and problems of compositional semantics in word formation]. Izv. $A N$ SSSR. Ser. lit. i yaz, 61, 1. 13-24.

Kubryakova, Ye. S. (2002). Kompozitsyonnaya semantika: tseli i zadachi [Compositional semantics: goals and objectives] Kompozitsyonnaya semantika: materialy tretiyey mezhdunarodnoy shk.-seminara po kognitivnoy lingvistike, September, 18-20, 2002, 1. 4-6.

Kubryakova, Ye. S. (2004). Yazyk $i$ znaniye. Na puti polucheniya znaniy o yazyke: Chasti reachi $s$ kognitivnoy tochki zreniya. Rol yazyka v poznanii [Language and knowledge. On the way to the knowledge about the language: Parts of speech from a cognitive point of view. The role of language in the cognition]. M. : Yazyki clavyanskoy kultury.

Kubryakova, Ye. S., Nogina, I. V. (1975). Problemy funktsyonirovaniya chastits tipa out v sisteme slovoobrazovaniya sovremennogo angliyskogo yazyka [Problems of functioning of out type particles in the wordformation system of modern English]. Slovoobrazovanie i ego mesto v kurse obucheniya inostrannomu yazyku. eds Ye. S. Kubryakova, I. V. Nogina, 3. 107-115.

Kucher, I. A. (2015). Lingvokognityvne modeliuvannya leksyko-semantychnogo polya diyesliv rukhu u finskiy $i$ ukrayiskiy movah [Linguocognitive modeling of the lexical-semantic field of verbs in the Finnish and Ukrainian languages]: Thesis' Abstract: 10.02.17. K. : KNLU.

Lakoff, G. (1995). Kognitivnoye modelirovaniye [Cognitive modelling]. Transl. from English. G. Lakoff. Yazyk $\mathrm{i}$ intellect. 143-184.

Langacker R. W. (1988). Overview of Cognitive Grammar. Amsterdam Studies in the Theory and History of Linguistic Science, IV, 50. 3-49.

Langacker, R. W. (1991). Concept, Image and Symbol: The Cognitive Basis of Grammar. Berlin : Mouton de Gruyter. 189-201.

Lindner, S. (1982). What goes up doesn't necessarily come down: The ins and outs of opposites. Papers from the 18th Regional Meeting. 305-323.

Lindner, S. (1983). A Lexico-Semantic Analysis of English Verb-Particle Constructions with UP and OUT. Trier: LAUT. 
Lindner, S. (2000). To, chto dvizhetsya vverh (up), yt obyazatelno mozhet sledovat vniz (down): sopostavleniye in $\mathrm{i}$ on [What moves up does not necessarily moves down: comparing in and on]. Translated from English by S. Lindner. Issledovaniya po semantike predlogov. $55-82$.

Malykh, D. S. (2009). Opredeleniye frazovogo glagola i problema posleloga [Definition of the phrasal verb and the postposition problem]. Lingua mobilis, 3 (17). 104-108.

Meyer C. F. (2002). English corpus linguistics: An introduction. Cambridge: Cambridge University Press.

Morgan, P. (1997). Figuring out 'figure out': Metaphor and the Semantics of the English Verb-Particle Construction. Cognitive Linguistics, 8 (4). 95-119.

Nikolenko, A. G. (1999). Leksyko-semantychni ta funktsionalni osoblyvosti vzayemodiyi komponentiv frazovyh diesliv suchasnoyi angliyskoyi movy [Lexico-semantic and functional characteristics of the interaction between the components of the phrasal verbs in modern English]: Thesis' Abstract: 10.02.04. K. : KNLU.

Nogina, I. V. (1977). O nominativnyh edinitsah tipa get out $v$ sovremennom angliyskom yazyke [On nominal units of get out type in modern English]: Thesis: 10.02.04. M. : MGPIIYA im. M. Toreza.

Paliy, O. S. (2008). Diyeslova z postpozytyvnymy komponentamy on i off v suchasniy angliyskiy movi [Verbs with post-positional components on and off in modern English]: Thesis' Abstract: 10.02.04. Donetsk : Donetskiy natsionalniy universytet.

Petrova, I. P. (2012). Kategorizatsiya mira angliyskimi somaticheskimi frazovymi glagolami [Categorization of the world with the English somatic phrasal verbs]: Thesis' Abstract: 10.02.04. Irkutsk: Irkutskiy gosudarstvenniy lingvisticheskiy universitet.

Petrovich, Y. V. (2004). Kognitivniye osnovy obrazovaniya novyh frazovyh glagolov $v$ sovremennom angliyskom yazyke [Cognitive foundations of the formation of new phrasal verbs in modern English]: Thesis: 10.02.04. Kaliningrad : Kaliningradskiy gosudarstvenniy universitet.

Povey, J. (1990). Phrasal Verbs and How to Use Them. M. : Vysshaya shkola.

Povey, J. (1990). Angliyskiye frazovye glagoly $i$ ih upotreblenie [Phrasal verbs and how to use them]. M. : Vysshaya shkola.

Shaposhnikova, I. V. (2003). Glagolnaya anallitichskaya nominatsiya kak teoreticheskaya i metodicheskaya problema $\mathrm{v}$ sovremennom angliyskom yazyke [Verbal analytical nomination as a theoretical and methodological problem in modern English]. Teoriya, istoriya, tipologiya yazykov: materialy chteniy pamyati $V$. N. Yartsevoy, 1. 202-211.

Sizova, I. A. (2004). K voprosu ob istokah frazovyh glagolov v angliyskom yazyke. Teskt. [To the issue of the origins of phrasal verbs in the English language. Text]. Vestnik IGU. Seriya: Lingvistika $i$ mezhkulturnaya kommunikatsiya, 2, 1. 149-156.

Smirnitskiy, A. I. (1998). Leksikologiya angliyskogo yazyka [Lexicology of the English language]. M. : Izdvo Omen. Drofa.

Smith, L. P. (1998). Frazeologiya angliyskogo yazyka [English phraseology]. Translated from English. M. :

Sweetser, E. (1999). Compositionality and Blending. Semantic Composition in a Cognitively Realistic Framework. Cognitive Linguistics: Foundations, Scope, and Methodology. 129-162.

Tesnière, L. (1988). Osnovy strukturnogo sintaksisa [Elements of structural syntax]. per. s fr. M. M. Boguslavskiy; vstup. st. V. G. Gak. M. : Progress.

Turner, M. (1995). Conceptual Integration and Formal Expression. Journal of Metaphor and Symbolic activity, 10, 3. 183-204.

Ufimtseva, A. A. (2002). Leksicheskoye znacheniye: Printsip semiologicheskogo opisaniya leksiki: monografiya [The lexical meaning: the principle of the semiological description of vocabulary: monograph]. 2-e izd. ster. M. : URSS.

Vanivska, O. I. (2010). Frazovi diyeslova v angliyskiy movi yak zasib vyrazhennya aspektualnogo znachennya inhoatyvnosti v Brytanskomu natsionalnomu korpusi (BNC) [Phrasal verbs in the English language as a means of expressing the aspect meaning of inchoativity in the British National Corpus (BNC)]. Studia Germanica et Romanica: Inozemni movy. Zarubizhna literatura. Metodyka vykladannya, 7, 3(21). 5-12.

Vlavatskaya, M. V. (2013). Teoreticheskiye osnovy kombinatornoy lingvistiki: leksikologicheskiy $i$ leksikograficheskiy aspekty (na material russkogo $i$ angliyskogo yazykov) [Theoretical fundamentals of combinatorial linguistics: lexicological and lexicographical aspects (on the materials of the Russian and English languages)]: Thesis' Abstract: 10.02.19. Kemerovo.

Voskres, A. A. (2014). Diyeslovo yak golovnyi component diyeslivno-adverbialnogo kompleksu [The verb as the main component of the verb-adverb complex]. Visnyk Kyivskoho natsionalnoho lingvistychnoho universytetu. Ser.: Filologiya, 17, 2. 31-37. 
Yatskovich, I. A. (2000). Kognitivniy aspekt slovarnogo perevoda angliyskih frazovyh glagolov [Cognitive aspect of lexical translation of English phrasal verbs]: Thesis: 10.02.20. Ufa.

Zhluktenko, U. A. (1954). O tak nazyvaemykh "slozhnyh glagolah" tipa stand up v sovremennom angliyskom yazyke [On the so-called "complex verbs" of the stand up type in modern English]. Voprosy yazykoznaniya, 5. 105-113.

Zilberman, L. I. (1958). Semantika narechnoy chastitsy up v sostave glagolnykh obrazovaniy tipa to stand up [The semantics of the adverb particle up in the structure of the to stand up type verb formations]. Romanogermanskaya filologiya, 2. 110-131.

\section{Бібліографічний опис:}

Бобер, Н.М.(2018). Фразові дієслова ангдійської мови як когнітивносемантичні комплекси та фрагмент багатовимірного знання матричного формату. Науковий часопис Національного педагогічного університету імені М. П. Арагоманова. Серія 9. Сучасні тенденції розвитку мов, 18. 22-32. DOI: https://doi.org/10.31392/NPUnc.series9.2018.18.02

\section{Анотація}

У статті пропонується новий підхід до вивчення фразових дієслів англійської мови, щя наразі активно розроблясться представниками когнітивної синтагматики. Спираючись на праці, виконані в рамках иьвого напряму, уточнено визначення фразових дієслів як когнітивно-семантичних комплексів, які відображають / описують певний фрагмент батовимірного знання матричного формату. Особливу увагу приділено критичному аналізу поглядів учених на проблему другого компонента цих утворень, які й донині не є однозначними як у плані обговорення виконуваних ними функцій у складі фразових дієслів, так і щодо їх морфологічної природи і у зв'язку з цим термінологічного позначення.

Зроблено припущення, що семантика фразових дієслів твориться при взаємодії конщептуальних структур як власне дієслова, так $i$ його другого компонента, де саме абстрактне значення останнього дає широкі можливості для випромінювання нових значень. У такому разі функиія обох компонентів композиційно складної мовної одиниці або когнітивно-семантичного комплексу, яким $\epsilon$ фразове дієслово, полягає у профілюванні певних аспектів описуваної ијим утворенням ситуації, щяо сприяє появі тих нових властивостей, які жоден із компонентів: ані дієслово, ані постпозитивний компонент не міг би описати / позначити окремо.

Доведено, щзо для англійської мови $є$ характерною когнітивно-семантична конструкиія “дієслово + постпозитивний компонент”, яка відображає певну граматичну схему комбінаторного конструювання фразових утворень на основі механізмів конщептуальної інтеграції, коли иляхом метафоричної селекиії вихідного ментального простору дієслова $i$ вихідного простору постпозитивного компонента утворюється новий бленд - нова конщептуальна структура, відсутня у вихідних ментальних просторах кожного з компонентів.

Ключові слова: фразові дієслова, когнітивно-семантичний комплекс, постпозитивний компонент, матричний формат, кониептуальна інтеграція. 